
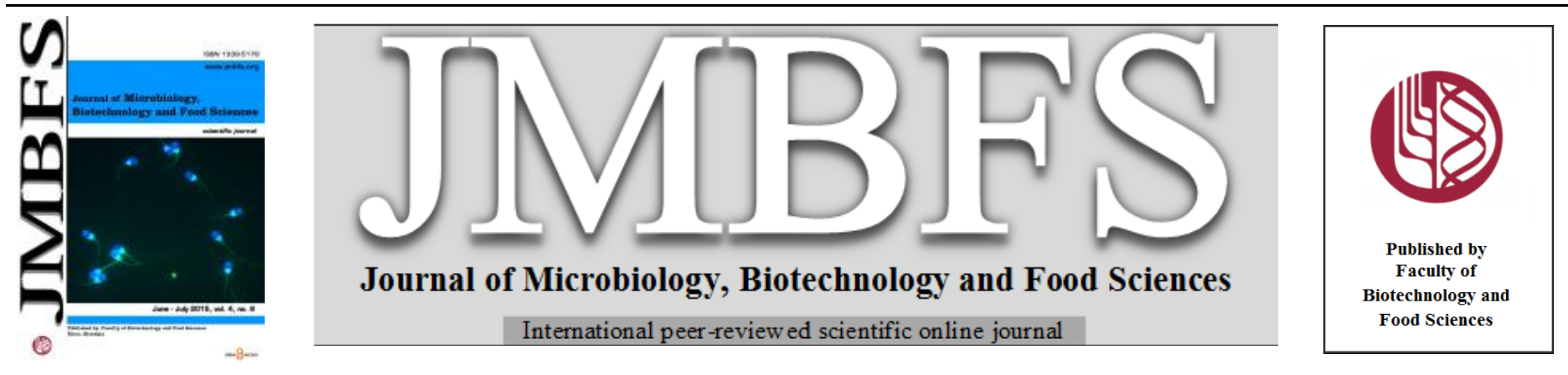

\title{
COMPARISON OF MICROBIOLOGICAL QUALITY OF READY-TO-EAT DELICATESSEN PRODUCT WITH RESPECT TO STORAGE TEMPERATURE
}

\author{
Simona Kunová ${ }^{1}$,Miroslava Kačániová ${ }^{2}$, Maciej Kluz ${ }^{3}$, Lubomír Lopašovský ${ }^{1}$
}

\section{Address(es):}

${ }^{1}$ Slovak University of Agriculture in Nitra, Faculty of Biotechnology and Food Sciences, Department of Food Hygiene and Safety, Tr. A. Hlinku 2, 94976 Nitra, Slovak Republic.

${ }^{2}$ Slovak University of Agriculture in Nitra, Faculty of Biotechnology and Food Sciences, Department of Microbiology, Tr. A. Hlinku 2, 94976 Nitra, Slovak Republic. ${ }^{3}$ Department of Biotechnology and Microbiology, Faculty of Biology and Agriculture, University of Rzeszow, Zelwerowicza 4, 35-601,

Rzeszow, Poland.

*Corresponding author: simona.kunova@gmail.com

doi: $10.15414 / j m b f s .2015 .4 .6 .560-563$

\section{ARTICLE INFO}

Received 16. 4. 2015

Revised 15. 5. 2015

Accepted 28. 5. 2015

Published 1. 6. 2015

Regular article OPEN $\partial_{\text {ACCESS }}$

\begin{abstract}
The aim of the present study was to evaluate microbiological quality of ready-to-eat (RTE) delicatessen food. Microbiological parameter were determined in 24 samples together. The safety of ready-to-eat food is an important issue. Improper handling of ready-to-eat food items may result in foodborne diseases outbreaks. Total Viable Count (TVC), coliforms bacteria (CB), microscopic filamentous fungi and yeasts (MFFaY) were determined. Plate dilution method with individual culture conditions was used for microorganisms cultivation. The minimal value of TVC in delicatessen products was $2.25 \mathrm{log}$ CFU. $\mathrm{g}^{-1}$ in sample no. 4 after opening and maximal value was $5.61 \log$ CFU.g ${ }^{-1}$ in sample no. 8 after 3 days of storage at $15^{\circ} \mathrm{C}$. The minimal value of MFFaY in RTE delicatessen products was < $1 \log$ CFU.g $\mathrm{g}^{-1}$ in sample no. 3 after opening and maximal value was $6.1 \mathrm{log}$ CFU.g ${ }^{-1}$ in sample no. 7 , after 3 days of storage at $15^{\circ} \mathrm{C}$. Sample no. 1 and 8 after storage of products at $4{ }^{\circ} \mathrm{C}$ weren't in accordance with Codex Alimentarius of Slovak Republic (2006). Only sample no. 2 after storage at $15{ }^{\circ} \mathrm{C}$ meets requirements of Codex Alimentarius of Slovak Republic (2006). The values of CB in all samples of delicacy products were lower than $1 \log \mathrm{CFU} \cdot \mathrm{g}^{-1}\left(10 \mathrm{CFU} \cdot \mathrm{g}^{-1}\right)$ after opening, after storage at $4{ }^{\circ} \mathrm{C}$ and $15^{\circ} \mathrm{C}$. All samples were in accordance with Codex Alimentarius of Slovak Republic (2006).
\end{abstract}

\section{INTRODUCTION}

Controlling and improving the quality and safety of chilled foods at all stages of the cold chain have always been among the main concerns in order to reduce food losses and health hazards. Microbial and physico-chemical quality changes may occur in food products according to their time-temperature history, but also according to their composition and properties (Mataragas et al., 2008; Verbeke et al., 2010).

The incidence of foodborne illness is increasing worldwide (Mead $\boldsymbol{e t}$ al., 1999; Nguz, 2007). This may in part be attributed to a change in commercial food production such as minimal processing as well as changing consumer demands for ready-to-eat (RTE) meals (Kaneko et al., 1996). The microbiology of RTE foods during preparation in factories, in domestic kitchens, in canteens and on street corners by street vendors has previously been investigated (Ayçiçek $\boldsymbol{e t}$ al., 2004; Baş et al., 2006; von Holy and Makhoane, 2006). However, the contamination of RTE foods that occurs in retail delicatessens has received relatively less attention (Angelidis et al., 2006). Ready-to-eat (RTE) foods are very attractive to consumers looking for convenient meals. Codex Alimentarius Commision defines the RTEs as: foods that include any food (including beverages) consumed in its raw state or any food handled, processed, mixed, cooked or otherwise prepared into a form in which it is normally consumed without further processing (Codex, 2004). As the demand for RTE foods increases, a greater variety of RTE foods are becoming available. RTE foods may vary according to different eating habits, availability, cold chain conditions and regulations in different countries (Almualla et al., 2010). Occurrence of pathogens in RTE foods presents a greater public health threat than its presence in raw meat products because RTE' are not usually subjected to sufficient temperature/time combination to destroy these bacteria before consumption (Osaili et al., 2011). RTE foods could contain the indigenous microflora of the raw materials from which they are prepared (Almualla et al., 2010). Ready-to-eat food is highly subject to bacterial foodborne outbreaks. Various foodborne pathogens associated with ready-to-eat food have been found to contribute to foodborne outbreaks (Castro-Rosas et al., 2012; Seow et al., 2012).

Methods of storage, processing, handling, and display can affect the levels of microorganisms in ready-to-eat food. Monitoring of the level of bacteria in readyto-eat food is important to ensure the safety of this type of high-risk food (Christison et al., 2008; Fang et al., 2003). Foodborne pathogens in salads or sandwiches may proliferate in the presence of low numbers of other microorganisms as a result of cooking of ingredients before production (Jay $\boldsymbol{e} t$ al., 2005).

The aim of this article was to evaluate the microbiological quality of RTE delicatessen products during storage at various temperatures.

\section{MATERIAL AND METHODS}

The aim of this article was to evaluate microbiological quality of selected RTE delicatessen products. There were analyzed 24 samples of delicatessen products. These products were evaluated: paprika spread (samples 1,2), cod salad (samples 3,4 ), egg in aspic (samples 5, 6) and parisian salad (samples 7, 8). There were analyzed 8 samples immadietly after opening, 8 samples after three days of storage at $4{ }^{\circ} \mathrm{C}$ and 8 samples after three days of storage at $15^{\circ} \mathrm{C}$

The total viable count (TVC), coliform bacteria (CB) and microscopic filamentous fungi and yeasts (MFFaY) were evaluated. The values of microorganisms were compared with requirements of Codex Alimentarius of Slovak Republic (2006).

\section{Determination of cfu counts}

Plate diluting method was applied for quantitative cfu counts of respective groups of microorganisms in $1 \mathrm{~g}$ of product. Gelatinous nutritive substrate in petri dishes was inoculated with $1 \mathrm{ml}$ of samples by flushing and on surface in three replications. 


\section{Dilution of the samples}

Basic dilution $\left(10^{-1}\right)$ was prepared as follows: $5 \mathrm{~g}$ of product was added to the test tube containing $45 \mathrm{ml}$ of distilled water. Dilution plating method was used to determine the microorganisms.

\section{Determination of TVC}

Plate Count Agar was used for determine of Total Viable Counts in samples. Dilutions of $10^{-3}$ and $10^{-4}$ were used to determine of TVC. Petri dishes were cultivated upside-down in a thermostat at $30{ }^{\circ} \mathrm{C}$ for $48-72$ hours under aerobic conditions.

\section{Determination of $\mathrm{CB}$}

Violet red bile agar was used for determine of Coliform Bacteria in samples Dilutions of $10^{-3}$ and $10^{-4}$ were used to determine of Coliform Bacteria. Petri dishes were cultivated upside-down in a thermostat at $37^{\circ} \mathrm{C}$ for $24-48$ hours.

\section{Determination of MFF}

Chloramfenicol yeast glucose agar was used for determine of Microscopic Filamentous Fungi. Dilutions of $10^{-1}$ and $10^{-2}$ were used to determine of MFF Petri dishes were cultivated upside-down in a thermostat at $25{ }^{\circ} \mathrm{C}$ for $5-7$ days under aerobic conditions.

\section{Calculation of microorganisms}

The number of microorganisms in $1 \mathrm{~g}$ samples $(\mathrm{N})$ were calculated using the following formula:

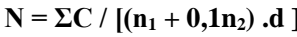

$\mathbf{\Sigma C}$ - sum of characteristic colonies on selected plates,

$\mathbf{n}_{\mathbf{1}}-$ number of dishes from 1. dilutions used to calculate,

$\mathbf{n}_{\mathbf{2}}-$ number of dishes from 2. dilutions used to calculate,

$\mathbf{d}$ - dilution factor identical with 1 . used dilution.

\section{Statistical Analysis}

Mathematical and statistical analysis (arithmetic mean, standard deviation, standard error, coefficient of variation) were performed using the program system Statgraffic.

\section{RESULTS AND DISCUSSION}

The Codex Alimentarius determines the maximal limit of coliform bacteria for salads with mayonnaise or without mayonnaise, spreads and products in aspic $10^{4} \mathrm{CFU}_{\mathrm{g}} \mathrm{g}^{-1}$ (4.00 $\left.\log \mathrm{CFU} \cdot \mathrm{g}^{-1}\right)$, the maximal limit of yeasts for salads with mayonnaise or without mayonnaise is $5 \times 10^{4}$ CFU.g ${ }^{-1}$, the maximal limit of yeasts for spreads and creams is $5 \times 10^{3} \mathrm{CFU} \cdot \mathrm{g}^{-1}$.

\section{Determination of total viable counts (TVC)}

Ng et al. (2013) were examinated 115 samples of ready-to-eat products from supermarkets. They were tested for aerobic plate counts (APC), Escherichia coli and Staphylococcus aureus counts, and the presence of Salmonella spp. for assessing their safety level. Results showed APC ranging from 1.97 to $6.84 \mathrm{log}$ CFU.g ${ }^{-1}$, with a mean of $5.05 \log$ CFU.g ${ }^{-1} ;$ E. coli counts ranging from none detected to $3.10 \log$ CFU.g ${ }^{-1}$, with a mean of $1.78 \log$ CFU.g ${ }^{-1}$; and $S$. aureus counts ranging from none detected to $1.42 \mathrm{log} C F U . g^{-1}$, with a mean of $0.15 \mathrm{log}$ CFU.g ${ }^{-1}$.

The values of TVC after opening ranged from $2.25 \mathrm{log}$ CFU. $\mathrm{g}^{-1}\left(1.81 \times 10^{2} \mathrm{CFU}\right.$. $\left.\mathrm{g}^{-1}\right)$ in sample no. 4 (cod salad) to $5.32 \mathrm{log}$ CFU. $\mathrm{g}^{-1}\left(2.12 \times 10^{5}\right.$ CFU.g $\left.{ }^{-1}\right)$ in sample no. 8 (parisean salad) (fig. 1). Average number of TVC was $3.76 \mathrm{log}$ CFU. $\mathrm{g}^{-1}$ (tab. 1)

Values of TVC after 3 days of storage at temperature $4{ }^{\circ} \mathrm{C}$ were in range from $3.19 \log$ CFU. $\mathrm{g}^{-1}\left(1.58 \times 10^{3}\right.$ CFU. $\left.\mathrm{g}^{-1}\right)$ in sample no .3 (cod salad) a to $5.37 \mathrm{log}$ CFU. $\mathrm{g}^{-1}\left(2.38 \times 10^{5} \mathrm{CFU} \cdot \mathrm{g}^{-1}\right)$ in sample no. 8 (parisean salad) (fig. 2). Average number of TVC was $4.47 \log$ CFU. $\mathrm{g}^{-1}$ (table 1 ).
TVC in samples after opening

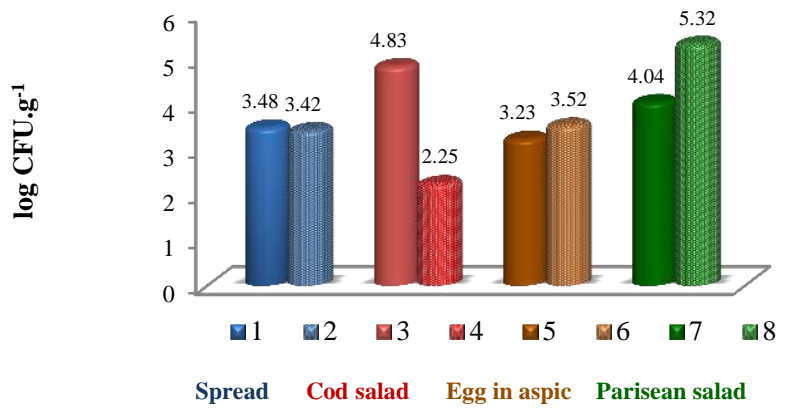

Figure 1 Determination of TVC in delicacy products after opening

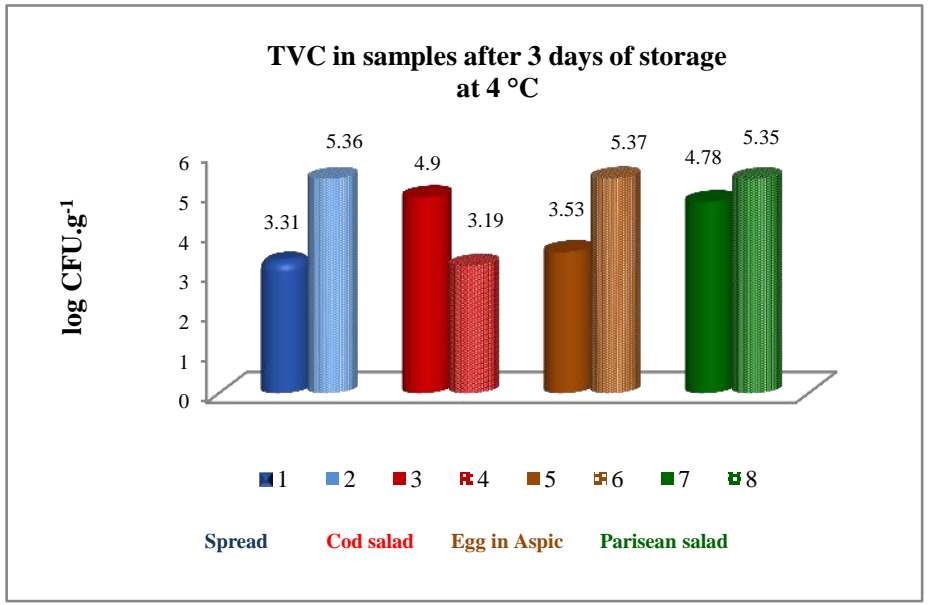

Figure 2 Determination of TVC in delicacy products after storage at $4{ }^{\circ} \mathrm{C}$

RTE foods provide a source of readily available and nutritious meals for the consumers, but as these foods do not receive any heat treatment before consumption, the first priority should be their safety and microbiological quality. The initial microbiological load on RTE food ingredients is important, but the microbiological load of RTE foods at the point of sale is influenced by factors such as handling, processing, storage and display (Smittle, 2000).

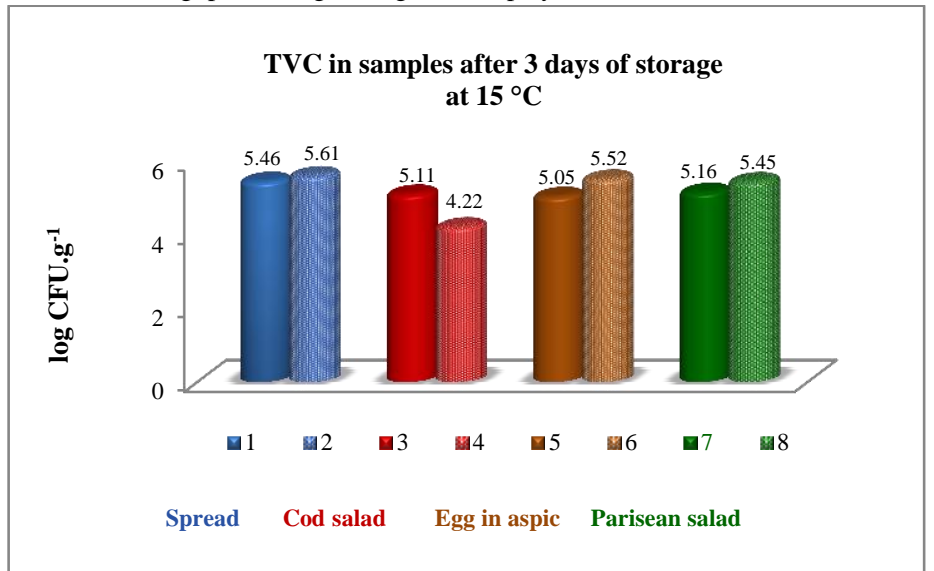

Figure 3 Determination of TVC in delicacy products after storage at $15^{\circ} \mathrm{C}$

Values of TVC after 3 days of storage at temperature $15^{\circ} \mathrm{C}$ ranged from $4.22 \mathrm{log}$ CFU.g ${ }^{-1}\left(1.67 \times 10^{4} \mathrm{CFU}_{\mathrm{g}}{ }^{-1}\right)$ in samle no. 4 to $5.61 \mathrm{log}$ CFU.g ${ }^{-1}\left(2.31 \times 10^{5} \mathrm{CFU} . \mathrm{g}\right.$ ${ }^{1}$ ) in sample no. 2 (fig. 3). Average number of TVC was $5.2 \log$ CFU.g ${ }^{-1}$ (tab. 1). As the main constituents of these products were sliced products (either meat products or cheese) cross-contamination via equipment (i.e. slicer) could also contribute to the high population of aerobic colony count. The application of stringent hygienic practices during handling of vegetables is also necessary, as many of the above products contained vegetables. Commercial mayonnaise do not support the growth or survival of foodborne pathogens (i.e. Salmonella, E. coli $\mathrm{O} 157: \mathrm{H} 7$ and L. monocytogenes) due to low $\mathrm{pH}$ and water activity and the 
presence of lysozyme in the whole eggs used in the production of commercial mayonnaise; but, food-service workers must use stringent hygienic practices to prevent microbial pathogen contamination during preparation, handling and storage (Smittle, 2000).

$\underline{\text { Table } 1 \text { Basic statistical characteristics of TVC in delicacy products }}$

\begin{tabular}{lccc}
\hline Parameter & $\begin{array}{c}\text { TVC after } \\
\text { opening }\end{array}$ & $\begin{array}{c}\text { TVC after } \\
\text { storage } \\
\text { at } \mathbf{4}^{\circ} \mathbf{C}\end{array}$ & $\begin{array}{c}\text { TVC after } \\
\text { storage } \\
\text { at } \mathbf{1 5}{ }^{\circ} \mathbf{C}\end{array}$ \\
\hline $\mathbf{n}$ & 8 & 8 & 8 \\
$\mathbf{x}$ & 3.76 & 4.47 & 5.2 \\
$\mathbf{s}$ & 0.9 & 0.9 & 0.42 \\
$\mathbf{v} \%$ & 23.96 & 20.13 & 8.07 \\
\hline
\end{tabular}

$\mathrm{n}$ - number of samples, $\mathrm{x}$ - average, $\mathrm{s}$ - standard deviation, $\mathrm{v} \%$ - coefficient of variation

A temperature of $8{ }^{\circ} \mathrm{C}$ is a realistic temperature abuse due to storage in canteens. But higher temperatures of storage, i.e. between 8 and $17{ }^{\circ} \mathrm{C}$, should not be permitted for RTE products, unless the self life is about $20 \mathrm{~h}$ when they are placed in stores and kept at $18^{\circ} \mathrm{C}$ (Fang et al., 2003).

\section{Determination of filamentous microscopic fungi and yeasts (MFFaY)}

Results of our experiments showed the presence of MFFaY in delicacy products after opening in amount from $<1 \log$ CFU.g ${ }^{-1}\left(<10\right.$ CFU.g $\left.{ }^{-1}\right)$ in sample no. 3 to $4,42 \log$ CFU.g ${ }^{-1}\left(2.68 \times 10^{4}\right.$ CFU.g $\left.{ }^{-1}\right)$ in sample no. 4 (fig 4). Average value of MFFaY was $3.13 \log$ CFU.g ${ }^{-1}$ (tab. 2). All samples of delicacy products were in accordance with Codex Alimentarius of Slovak Republic (2006).

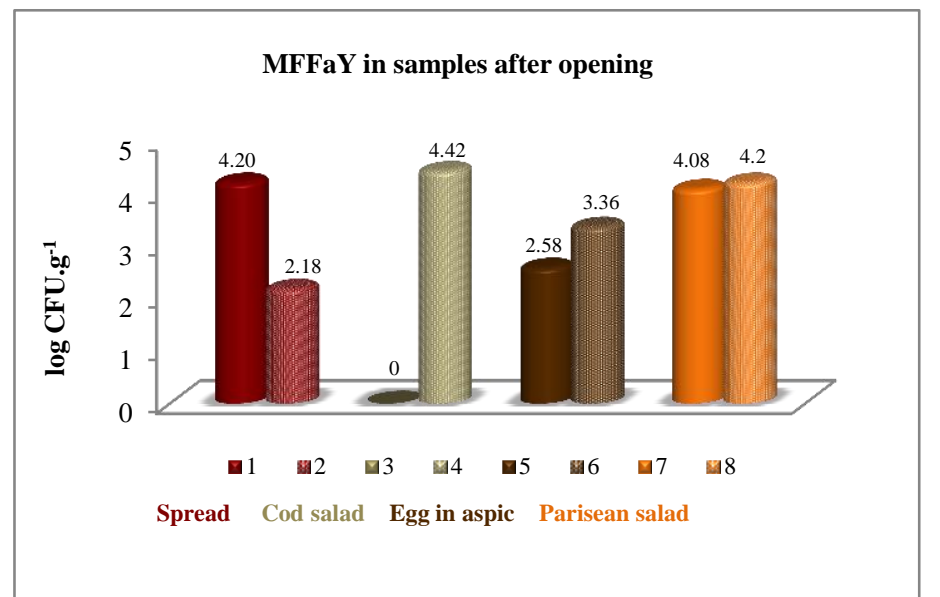

Figure 4 Determination of MFFaY in delicacy products after opening

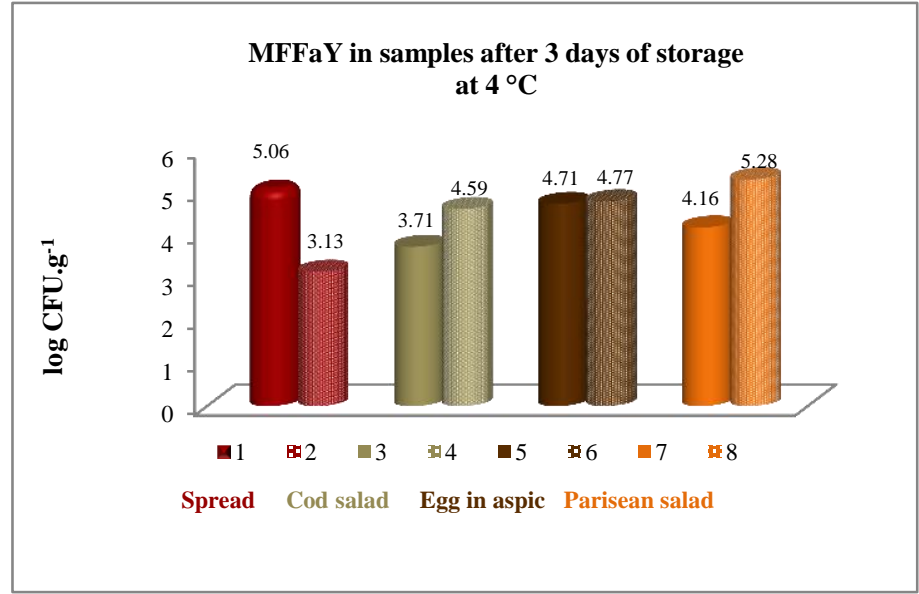

Figure 5 Determination of MFFaY in delicacy products after storage at $4{ }^{\circ} \mathrm{C}$

Values MFFaY in delicacy products after 3 days of storage at temperature $4{ }^{\circ} \mathrm{C}$ ranged from $3.13 \mathrm{log}$ CFU.g ${ }^{-1}\left(1.36 \times 10^{3} \mathrm{CFU}_{\mathrm{g}} \mathrm{g}^{-1}\right)$ in sample no. 2 to $5.28 \mathrm{log}$ CFU.g ${ }^{-1}\left(1.92 \times 10^{5} \mathrm{CFU}_{\mathrm{g}} \mathrm{g}^{-1}\right)$ in sample no. 8. Average number of MFFaY was $4.43 \log$ CFU.g ${ }^{-1}$ (tab. 2). Sample no. 1 and 8 weren't in accordance with Codex Alimentarius of Slovak Republic (2006).

Kanatt et al. (2006) found that the total viable bacterial count, Staphylococcus species and aerobic spore counts in samples of shrimp salad were in the range of $10^{1}-10^{3}$ CFU.g ${ }^{-1}, 10^{0}-10^{1}$ CFU.g ${ }^{-1}$ and $10^{1}-10^{2}$ CFU.g ${ }^{-1}$, respectively.

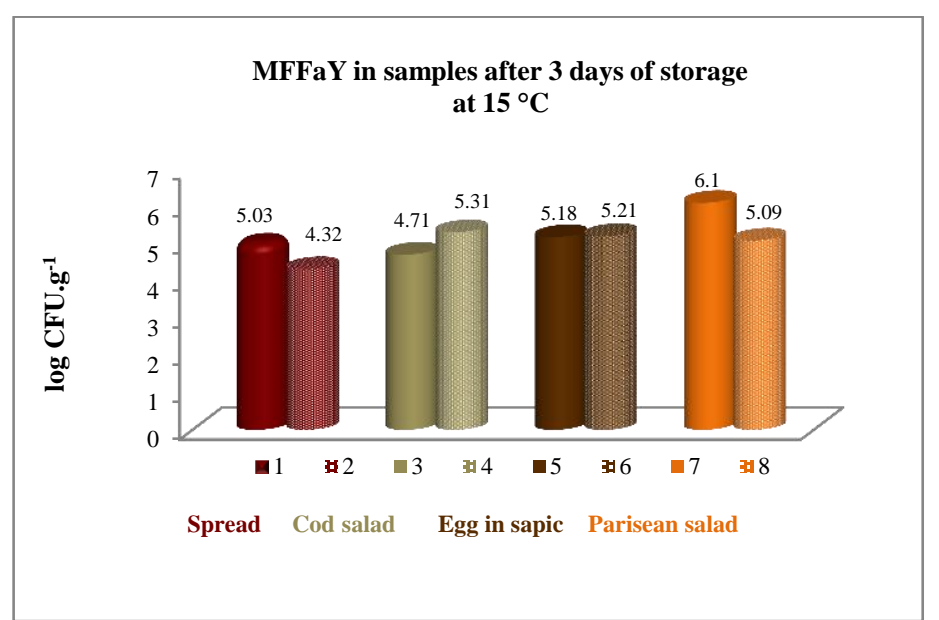

Figure 6 Determination of MFFaY in delicacy products after storage at $15^{\circ} \mathrm{C}$

Values MFFaY in delicacy products after 3 days of storage at temperature $15^{\circ} \mathrm{C}$ were in range from $4.32 \mathrm{log}$ CFU.g ${ }^{-1}\left(2.09 \times 10^{4}\right.$ CFU.g $\left.{ }^{-1}\right)$ in sample no. 2 to 6.1 $\log \mathrm{CFU} . \mathrm{g}^{-1}\left(1.26 \times 10^{6} \mathrm{CFU} \cdot \mathrm{g}^{-1}\right)$ in sample no. 7 (fig. 6). Average number of MFFaY was $5.12 \log$ CFU.g $g^{-1}$ (tab. 2). Only sample no. 2 meets requirements of Codex Alimentarius of Slovak Republic (2006).

Table 2 Basic statistical characteristics of MFFaY in delicacy products

\begin{tabular}{lccc}
\hline Parameter & $\begin{array}{c}\text { MFFaY after } \\
\text { opening }\end{array}$ & $\begin{array}{c}\text { MFFaY after } \\
\text { storage at } \mathbf{~}^{\circ} \mathbf{C}\end{array}$ & $\begin{array}{c}\text { MFFaY after } \\
\text { storage at 15 }\end{array}{ }^{\circ} \mathbf{C}$ \\
\hline $\mathbf{n}$ & 8 & 8 & 8 \\
$\mathbf{x}$ & 3.13 & 4.43 & 5.12 \\
$\mathbf{S}$ & 1.41 & 0.67 & 0.48 \\
$\mathbf{v} \%$ & 45.04 & 15.12 & 9.37 \\
\hline
\end{tabular}

$\mathrm{n}$ - number of samples, $\mathrm{x}$ - average, $\mathrm{s}$ - standard deviation, $\mathrm{v} \%$ - coefficient of variation

Mold growth was observed in samples of shrimps salads. Molds can grow even at a low awaw of 0.60 (Jay, 2000). Mold growth has been observed in foods having a awaw greater than 0.75 In mutton kababs having awaw of 0.85 mold growth was observed when stored at ambient temperature (Chawla and Chander, 2004).

Determination of coliform bacteria $(\mathrm{CB})$

The values of $\mathrm{CB}$ in all samples of delicacy products were lower than 1 log CFU. ${ }^{-1}$ (10 CFU.g ${ }^{-1}$ ) after opening, after storage at $4{ }^{\circ} \mathrm{C}$ and $15{ }^{\circ} \mathrm{C}$ (tab. 3). All samples were in accordance with Codex Alimentarius of Slovak Republic (2006). Christisin et al. (2008) showed, that aerobic plate counts were $10^{9} \mathrm{CFU} \cdot \mathrm{g}^{-1}$ for filled baguettes from retail delicatessens in South Africa. High aerobic colony counts alone do not make foods unsafe, but they indicate poor handling, storage or inadequate general hygiene (Gillespie et al., 2000). But, samples are of unsatisfactory microbiological quality because of high aerobic colony counts $\left(\geq 10^{7} \mathrm{CFU} . \mathrm{g}^{-1}\right.$ for cooked ham; $\geq 10^{6} \mathrm{CFU} . \mathrm{g}^{-1}$ for other sliced meat samples) or high levels of Enterobacteriaceae ( $\left.\geq 10^{4} \mathrm{CFU} \cdot \mathrm{g}^{-1}\right)$ (Elson et al., 2004).

Table 3 Determination of CB in delicacy products

\begin{tabular}{|c|c|c|c|c|c|c|}
\hline \multirow{2}{*}{ Sample } & \multicolumn{2}{|c|}{ CB after opening } & \multicolumn{2}{|c|}{$\begin{array}{c}\text { CB after storage at } \\
44^{\circ} \mathrm{C}\end{array}$} & \multicolumn{2}{|c|}{$\begin{array}{l}\text { CB after storage at } \\
15^{\circ} \mathrm{C}\end{array}$} \\
\hline & $\underset{1}{C F U . g^{-}}$ & $\begin{array}{c}\log \\
\text { CFU.g }^{-1}\end{array}$ & $\underset{1}{\text { CFU.g }}$ & $\begin{array}{c}\log \\
\text { CFU.g }^{-1}\end{array}$ & $\underset{1}{\text { CFU.g }}$ & $\begin{array}{c}\log \\
\text { CFU.g } \\
\end{array}$ \\
\hline 1 & $<10$ & $<1$ & $<10$ & $<1$ & $<10$ & $<1$ \\
\hline 2 & $<10$ & $<1$ & $<10$ & $<1$ & $<10$ & $<1$ \\
\hline 3 & $<10$ & $<1$ & $<10$ & $<1$ & $<10$ & $<1$ \\
\hline 4 & $<10$ & $<1$ & $<10$ & $<1$ & $<10$ & $<1$ \\
\hline 5 & $<10$ & $<1$ & $<10$ & $<1$ & $<10$ & $<1$ \\
\hline 6 & $<10$ & $<1$ & $<10$ & $<1$ & $<10$ & $<1$ \\
\hline 7 & $<10$ & $<1$ & $<10$ & $<1$ & $<10$ & $<1$ \\
\hline 8 & $<10$ & $<1$ & $<10$ & $<1$ & $<10$ & $<1$ \\
\hline
\end{tabular}

The use of coliforms as indicators of cross-contamination in RTE foods has limited application as these bacteria may occur naturally on fresh produce, such as vegetables (De Roever, 1998). For food commodities, more importance is generally placed on the presence and numbers of $E$. coli as indicators of crosscontamination (De Roever, 1998). Fang et al. (2003) found, that E. coli counts were highest on meat- and cheese-based filled baguettes, and salads containing meat. It has been suggested that several factors may contribute to the presence of $E$. coli in RTE foods, including poor handling practices by food handlers, or cross contamination from food contact surfaces, or high storage temperatures. This 
study did find that the core temperatures of both RTE food types were double that commonly recommended for RTE food storage, which indicated improper storage of these RTE food commodities.

\section{CONCLUSION}

The results for the aerobic colony count indicate that the general principles of good manufacturing programs and food hygiene as well as the temperature control should be enforced. Maintenance of correct refrigeration is fundamental for the safety of RTE foods. The results of the present study, can provide valuable information for the design of monitoring and surveillance programs for the official food microbiological control. Although the production of safe food is the responsibility of the producer, there is a need to verify and validate through inspection and end-product testing both at the site of production and at the poin of sale. RTE foods should be sold to the consumer as bacteriologically safe products.

Acknowledgments: The paper was supported by the project: The research leading to these results has received funding from the European Community under project no 26220220180: Building Research Centre „AgroBioTech“

\section{REFERENCES}

ALMUALlA, N.A., LALEYE, L.C., ABUSHELAIBI, A.A., AL-QASSEMI R.A., WASESA, A.A., BABOUCARR, J. 2010. Aspects of the microbiological quality and safety of ready-to-eat foods in Sharjah Supermarkets in the United Arab Emirates. Journal of Food Protection, 77 (7) 1328-1331.

ANGELIDIS, A.S., CHRONIS, E.N., PAPAGEORGIOU, D.K., KAZAKIS, I.I., ARSENOGLOU, K.C., STATHOPOULOS, G.A. 2006. Non-lactic acid contaminating flora in ready-to-eat foods: A potential food-quality index. Food Microbiology, 23 (1), 95-100. http://dx.doi.org/10.1016/j.fm.2005.01.015

AYÇIÇEK, H., SARIMEHMETOĞLU, B., ÇAKIROĞLU, S.2004. Assessment of the microbiological quality of meals sampled at the meal serving units of a military hospital in Ankara, Turkey. Food Control, 15 (5), 379-384. http://dx.doi.org/10.1016/s0956-7135(03)00101-4

BAŞ, M., ERSUN, A.S., KIVANÇ, G. 2006. The evaluation of food hygiene knowledge, attitudes and practices of food handlers' in food businesses in $\begin{array}{lllll}\text { Turkey. } & \text { Food } & \text { Control, } & 17 & \text { (4), }\end{array}$ http://dx.doi.org/10.1016/j.foodcont.2004.11.006

CASTRO-ROSAS, J., CERNA-CORTÉS, J.F., MÉNDEZ-REYES, E., LOPEZHERNANDEZ, D., GÓMEZ-ALDAPA, C.A., ESTRADA-GARCIA, T. 2012 Presence of faecal coliforms, Escherichia coli and diarrheagenic E. coli pathotypes in ready-to-eat salads, from an area where crops are irrigated with untreated sewage water. International Journal of Food Microbiology, 156 (2), 176-180. http://dx.doi.org/10.1016/j.ijfoodmicro.2012.03.025

CHAWLA, S.P., CHANDER, R. 2004. Microbiological safety of shelf-stable meat products prepared by employing hurdle technology. Food Control, 15 (7), 559-563. http://dx.doi.org/10.1016/j.foodcont.2003.09.001

CHRISTISON, C.A., LINDSAY, D., VON HOLY, A. 2008. Microbiological survey of ready-to-eat foods and associated preparation surfaces in retail delicatessens, Johannesburg, South Africa Food Control, 19 (7), 727-733. http://dx.doi.org/10.1016/j.foodcont.2007.07.004

CODEX ALIMENTARIUS SR 2006: II. čast' - štvrtá hlava, § 4 Mikrobiologické požiadavky na potraviny a na obaly na ich balenie. Výnos MP SR a MZ SR zo 6. februára 2006 č. 06267/2006-SL, ktorým sa vydáva hlava PK SR upravujúca mikrobiologické požiadavky na potraviny a na obaly na ich balenie.

CODEX ALIMENTARIUS COMMISION. 2004. Risk Assesment of Listeria monocytogenes. In Ready to Eat Foods: Guidelines FAO/WHO Microbiological Risk Assesment Series, 4Food and Agriculture Organisation, Rome.

DE ROEVER, C. 1998. Microbiological safety evaluations and recommendations on fresh produce. Food Control, 9 (6), 321-347. http://dx.doi.org/10.1016/s09567135(98)00022-X

ELSON, R., BURGESS, F., LITTLE, C.L., MITCHELL, R.T. 2004. Microbiological examination of ready-to-eat cold sliced meats and pâté from catering and retail premises in the UK. Journal of Applied Microbiology, 96 (3), 499-509. http://dx.doi.org/10.1111/j.1365-2672.2004.02203.x

FANG, T.J, WEI, Q. K., LIAO, C.W., HUNG, M. J., WANG, T. H. 2003 Microbiological quality of $18{ }^{\circ} \mathrm{C}$ ready-to-eat food products sold in Taiwan. International Journal of Food Microbiology, 80 (3), 241-250. http://dx.doi.org/10.1016/s0168-1605(02)00172-1

GILLESPIE, I., LITTLE, C., MITCHELL, R. 2000. Microbiological examination of cold ready-to-eat sliced meats from catering establishments in the United Kingdom. Journal of Applied Microbiology, 88 (3), 467-474. http://dx.doi.org/10.1046/j.1365-2672.2000.00981.x

JAY, J.M., LOESSNER, M.J., GOLDEN, A.A. 2005. Modern Food Microbiology (7th ed.) Aspen Publishers Inc., Gaithersburg, Maryland, USA.

JAY, J.M. 2000. Intrinsic and extrinsic parameters of foods that affect microbial growth. Modern Food Microbiology, 35-36. http://dx.doi.org/10.1007/978-14615-4427-2_3
KANATT, S.R., CHAWLA, S.P., CHANDER, R., SHARMA, A. 2006. Development of shelf-stable, ready-to-eat (RTE) shrimps (Penaeus indicus ) using $\gamma \gamma$-radiation as one of the hurdles. LWT - Food Science and Technology, 39 (6), 621-626. http://dx.doi.org/10.1016/j.1wt.2005.03.016

KANEKO, K. I., HAYASHIDANI, H., OHTOMO, Y., KOSUGE, J., KATO, M., TAKAHASHI, K. et al.1999. Bacterial contamination of ready-to-eat foods and fresh products in retail shops and food factories. Journal of Food Protection, 62 (6), 44-649.

MATARAGAS, M., SKANDAMIS, P.N., DROSINOS, E.H. 2008. Risk profiles of pork and poultry meat and risk ratings of various pathogen/product combinations. International Journal of Food Microbiology, 126 (1-2) 1-12. http://dx.doi.org/10.1016/j.ijfoodmicro.2008.05.014

MEAD, P.S., SLUTSKER, L., DIETZ, V., MCCAIG, L.F., BRESEE, J.S., SHAPIRO, et al. 1999. Food-related illness and death in the United States. Emerging Infectious Diseases, 5 (5), 607-625. http://dx.doi.org/10.3201/eid0505.990502

NG, Y.F., WONG, S.L., CHENG, H.L., YU, P.H.F., CHAN' S.W. 2013. The microbiological quality of ready-to-eat food in Siu Mei AND Lo Mei shops in Hong Kong. Food control, 34, (2), 547-553. http://dx.doi.org/10.1016/j.foodcont.2013.05.018

NGUZ, K. 2007. Assessing food safety system in sub-Saharan countries: An overview of key issues. Food Control, 18 (2), 131-134. http://dx.doi.org/10.1016/j.foodcont.2005.09.003

OSAILI, T.M., ALABOUDI, A.R., NESIAR, E.A. 2011. Prevalence of Listeria spp. and antibiotic susceptibility of Listeria monocytogenes isolated from raw chicken and ready to eat chicken products in Jordan. Food Control, 22 (3-4), 586-590. http://dx.doi.org/10.1016/j.foodcont.2010.10.008

SEOW, J., ÁGOSTON, R., PHUA, L., YUK, H.G. 2012. Microbiological quality of fresh vegetables and fruits sold in Singapore. Food Control, 25 (1), 39-44 http://dx.doi.org/10.1016/j.foodcont.2011.10.017

SMITTLE, R.B. 2000. Microbiological safety of mayonnaise, salad dressings, and sauces produced in the United States: a review. Journal of Food Protection, $63(8), 1144-1153$.

VERBEKE, W., PÉREZ-CUETO, F.J.A., DE BARCELLOS, M.D., KRYSTALLIS, A., GRUNERT, K.G. 2010. European citizen and consumer attitudes and preferences regarding beef and pork. Meat Science, 84 (2), 284 292. http://dx.doi.org/10.1016/j.meatsci.2009.05.001

VON HOLY, A., MAKHOANE, F.M. 2006. Improving street food vending in South Africa: Achievements and lessons learned. International Journal of Food Microbiology, 111 http://dx.doi.org/10.1016/j.ijfoodmicro.2006.06.012 